\title{
Combination treatment including targeted therapy for advanced hepatocellular carcinoma
}

\author{
Jianzhen Lin ${ }^{1, *}$, Liangcai Wu ${ }^{1, *}$, Xue Bai ${ }^{1, *}$, Yuan Xie ${ }^{1}$, Anqiang Wang ${ }^{1}$, Haohai \\ Zhang ${ }^{1}$, Xiaobo Yang ${ }^{1}$, Xueshuai Wan ${ }^{1}$, Xin Lu ${ }^{1}$, Xinting Sang ${ }^{1}$ and Haitao Zhao ${ }^{1,2}$ \\ ${ }^{1}$ Department of Liver Surgery, Peking Union Medical College Hospital, Chinese Academy of Medical Sciences and Peking \\ Union Medical College (CAMS \& PUMC), Beijing, China \\ ${ }^{2}$ Center of Translational Medicine, Peking Union Medical College Hospital, Chinese Academy of Medical Sciences and Peking \\ Union Medical College, Beijing, China \\ * These authors contributed equally to this work \\ Correspondence to: Xin Lu, email: IuxinIn@163.com
}

Xinting Sang, email: sangxinting@hotmail.com

Haitao Zhao, email: zhaoht@pumch.cn

Keywords: targeted therapy, combination treatment, hepatocellular carcinoma, molecular targeted agents

Received: June 01, 2016

Accepted: September 05, 2016

Published: September 10, 2016

\section{ABSTRACT}

Management of advanced hepatocellular carcinoma (HCC), one of the most lethal cancers worldwide, has presented a therapeutic challenge over past decades. Most patients with advanced HCC and a low possibility of surgical resection have limited treatment options and no alternative but to accept local or palliative treatment. In the new era of cancer therapy, increasing numbers of molecular targeted agents (MTAs) have been applied in the treatment of advanced HCC. However, mono-targeted therapy has shown disappointing outcomes in disease control, primarily because of tumor heterogeneity and complex cell signal transduction. Because incapacitation of a single target is insufficient for cancer suppression, combination treatment for targeted therapy has been proposed and experimentally tested in several clinical trials. In this article, we review research studies aimed to enhance the efficacy of targeted therapy for HCC through combination strategies. Combination treatments involving targeted therapy for advanced HCC are compared and discussed.

\section{INTRODUCTION}

$\mathrm{HCC}$ is the fifth most commonly diagnosed cancer and the second most common cause of cancer deaths worldwide [1]. For most patients with HCC, the diagnosis is delayed and the prognosis is poor. The median overall survival (OS) in patients with advanced HCC is less than 1 year, mainly owing to the absence of effective therapies [2]. When the diagnosis is confirmed, $70 \%$ to $80 \%$ of HCC patients have lost the opportunity to undergo complete tumor resection [3]. As it is impossible to perform curative therapies, patients with advanced HCC have to rely on non-surgical therapies such as chemotherapy, transcatheter arterial chemoembolization or embolization (TACE or TAE), radiotherapy, percutaneous ethanol injection (PEI), targeted therapy, or immunotherapy to prolong their survival time [4-7].
Although there are various options for non-surgical management of HCC, few therapies appear to effectively improve prognosis $[8,9]$. In the new era of the war against cancer, targeted therapy based on MTAs has gradually became an indispensable component of the treatment regimen for patients with advanced cancer. However, in many cases, low efficacy and drug resistance hamper the clinical application of MTAs, especially in the treatment of HCC [10]. Most MTAs, such as sunitinib, brivanib, linifanib, everolimus, ramucirumab, and sorafenib, show only a slight anticancer effect in advanced HCC [11]. For example, sorafenib, a small inhibitor of multiple tyrosine protein kinases that is considered the most efficient targeted drug for advanced HCC to date, has been proved to extend median OS by only 3 months with tolerable adverse events according to two large sample clinical trials $[12,13]$. Moreover, patients who initially respond to 
Table 1: Clinical trials regarding chemotherapy combine with targeted therapy (with published results).

\begin{tabular}{|c|c|c|c|c|c|c|c|}
\hline Agents & Stage & Patients(n) & Therapeutic shceme & $\begin{array}{l}\text { First or } \\
\text { second } \\
\text { line }\end{array}$ & \begin{tabular}{|l|} 
Efficacy \\
(combined \\
therapy vs \\
monotherapy)
\end{tabular} & $\begin{array}{l}\text { Adverse events } \\
\text { (AEs) }\end{array}$ & Ref \\
\hline $\begin{array}{l}\text { Doxorubici } \\
+ \\
\text { Sorafenib }\end{array}$ & $\begin{array}{l}\text { Phase } \\
2\end{array}$ & 96 & $\begin{array}{l}\text { Sorafenib } 400 \mathrm{mg} \text { bid } \\
\text { po plus doxorubicin } \\
60 \mathrm{mg} / \mathrm{m}^{2} / 21 \text { days i.v. } n \\
=47) \text { vs doxorubicin } \\
\text { monotherapy }(60 \mathrm{mg} / \\
\left.\mathrm{m}^{2} / 21 \text { days i.v. } n=48\right)\end{array}$ & First line & $\begin{array}{l}\text { mTTP: } 6.4 \text { vs. } \\
\text { 2.8 months } \\
\text { mPFS: } 6.0 \text { vs. } 2.7 \\
\text { months } \\
\text { mOS: } 13.7 \text { vs. } \\
6.5 \text { months }\end{array}$ & $\begin{array}{l}\text { fatigue, } \\
\text { dermatology/ } \\
\text { skin, hand-foot } \\
\text { skin reaction, } \\
\text { hematologic } \\
\text { (neutropenia, } \\
\text { leukopenia) }\end{array}$ & {$[1]$} \\
\hline $\begin{array}{l}\text { Erlotinib } \\
+ \\
\text { Docetaxel }\end{array}$ & $\begin{array}{l}\text { Phase } \\
1\end{array}$ & $\begin{array}{l}25 \\
\mathrm{HCC})\end{array}$ & $\begin{array}{l}\text { Docetaxel } 30 \mathrm{mg} / \mathrm{m}^{2} \\
\text { i.v. plus erlotinib } 150 \\
\text { mg po of each } 28 \text {-day } \\
\text { cycle. }\end{array}$ & First line & $\begin{array}{l}\text { 16-week PFS: } \\
\text { 38\%-HCC. } \\
\text { mOS: } 6.7 \\
\text { months-HCC }\end{array}$ & $\begin{array}{l}\text { rash, diarrhea, } \\
\text { fatigue }\end{array}$ & {$[2]$} \\
\hline $\begin{array}{l}\text { Bevacizumab + } \\
\text { Capecitabine }\end{array}$ & $\begin{array}{l}\text { Phase } \\
2\end{array}$ & 45 & $\begin{array}{l}\text { Bevacizumab } 7.5 \mathrm{mg} / \\
\mathrm{kg} \text { i.v. plus capecitabine } \\
800 \mathrm{mg} / \mathrm{m}^{2} \text { bid po every } \\
3 \text { weeks. }\end{array}$ & First line & $\begin{array}{l}\text { ORR: } 9 \% \text {; DCR: } \\
52 \% \\
\text { mPFS: } 2.7 \\
\text { months } \\
\text { mOS: } 5.9 \text { months }\end{array}$ & $\begin{array}{l}\text { diarrhoea, } \\
\text { nausea/ vomiting, } \\
\text { gastrointestinal } \\
\text { bleeding, hand-- } \\
\text { foot syndrome, } \\
\text { lower respiratory } \\
\text { tract infection and } \\
\text { proteinuria. } \\
\end{array}$ & {$[3]$} \\
\hline $\begin{array}{l}\text { Bevacizumab+ } \\
\text { Capecitabine + } \\
\text { Oxaliplatin }\end{array}$ & $\begin{array}{l}\text { Phase } \\
2\end{array}$ & 40 & $\begin{array}{l}\text { Each treatment } \\
\text { cycle was } 21 \text { days. } \\
\text { Bevacizumab } 5 \mathrm{mg} / \mathrm{kg} \\
\text { i.v. and oxaliplatin } 130 \\
\mathrm{mg} / \mathrm{m}^{2} \text { i.v. Capecitabine } \\
825 \mathrm{mg} / \mathrm{m}^{2} \text { bid po. } \\
\end{array}$ & First line & $\begin{array}{l}\text { mPFS: } 6.8 \\
\text { months } \\
\text { mOS: } 9.8 \text { months } \\
\text { DCR: } 77.5 \%\end{array}$ & $\begin{array}{l}\text { sensory } \\
\text { neuropathy, fatigue } \\
\text { and diarrhea. }\end{array}$ & {$[4]$} \\
\hline $\begin{array}{l}\text { Gemcitabin } \\
+ \\
\text { Oxaliplatin } \\
+ \text { Bevacizumab }\end{array}$ & $\begin{array}{l}\text { Phase } \\
2\end{array}$ & 30 & $\begin{array}{l}\text { For cycle } 1 \text { ( } 14 \text { days), } \\
\text { bevacizumab } 10 \mathrm{mg} / \\
\mathrm{kg} \text { alone i.v. For cycle } \\
2 \text { and beyond ( } 28 \text { days/ } \\
\text { cycle), bevacizumab } \\
10 \mathrm{mg} / \mathrm{kg} \text {. Gemcitabine } \\
1,000 \mathrm{mg} / \mathrm{m}^{2} . \\
\text { Oxaliplatin at } 85 \mathrm{mg} / \\
\mathrm{m}^{2} \text {. }\end{array}$ & First line & $\begin{array}{l}\text { ORR: } 20 \% \\
\text { mOS: } 9.6 \text { months } \\
\text { mPFS: } 5.3 \\
\text { months. }\end{array}$ & $\begin{array}{l}\text { leukopenia/ } \\
\text { neutropenia, } \\
\text { transient } \\
\text { elevation of } \\
\text { aminotransferases, } \\
\text { hypertension and } \\
\text { fatigue. }\end{array}$ & {$[5]$} \\
\hline $\begin{array}{l}\text { Gemcitabine } \\
+ \text { Oxaliplatin } \\
\text { (GEMOX) } \\
+ \\
\text { Cetuximab } \\
\end{array}$ & $\begin{array}{l}\text { Phase } \\
2\end{array}$ & 45 & $\begin{array}{l}\text { Cetuximab } 400 \mathrm{mg} / \mathrm{m}^{2} \\
\text { initially then } 250 \mathrm{mg} / \\
\mathrm{m}^{2} \text { weekly; gemcitabine } \\
1000 \mathrm{mg} / \mathrm{m}^{2} ; \text { oxaliplatin } \\
100 \mathrm{mg} / \mathrm{m}^{2} \text {. }\end{array}$ & First line & \begin{tabular}{|l|} 
mPFS: 4.7 \\
months \\
mOS: 9.5 months \\
1-year survival \\
rate: $40 \%$. \\
\end{tabular} & $\begin{array}{l}\text { thrombocytopenia, } \\
\text { neutropenia and } \\
\text { anemia. }\end{array}$ & {$[6]$} \\
\hline $\begin{array}{l}\text { Capecitabine } \\
+ \\
+ \\
\text { Oxaliplatin } \\
+ \\
\text { Cetuximab }\end{array}$ & $\begin{array}{l}\text { Phase } \\
2\end{array}$ & 29 & $\begin{array}{l}\text { oxaliplatin } 130 \mathrm{mg} / \\
\mathrm{m}^{2} \text { i.v. plus cetuximab } \\
400 \mathrm{mg} / \mathrm{m}^{2} \mathrm{IV} \text { on day } 1 \\
\text { of cycle } 1 \text { followed by } \\
250 \mathrm{mg} / \mathrm{m}^{2} \text { iv weekly, } \\
\text { capecitabine } 850 \mathrm{mg} / \mathrm{m}^{2} \\
\text { PO Bid. }\end{array}$ & First line & $\begin{array}{l}\text { DCR: } 83 \% \\
\text { mTTP: } 4.5 \\
\text { months } \\
\text { mPFS: } 3.3 \\
\text { months } \\
\text { mOS: } 4.4 \\
\text { months. } \\
\end{array}$ & $\begin{array}{l}\text { fatigue, diarrhea, } \\
\text { and mucositis. }\end{array}$ & {$[7]$} \\
\hline
\end{tabular}

Abbreviations: mOS: median overall survival; mPFS: median progression-free survival; mTTP: median time to progression; DCR: disease control rate; ORR: objective response rate; PFR: progression-free rate.

therapy eventually suffer cancer progression. The median progression-free survival (PFS) is prolonged by MTAs, but few patients achieve complete response and extended OS [14].

To counteract the low efficacy of monotargeted therapy, the concept of combination therapy based on MTAs for the comprehensive treatment of cancer has been proposed in recent years [15], including in the treatment of HCC [16]. Here, we reviewed relevant studies and clinical trials concerning combination treatments based on targeted therapy agents for advanced $\mathrm{HCC}$, and discuss the current status of clinical applications for this novel strategy. 


\section{TARGETED THERAPY WITH CHEMOTHERAPY \\ COMBINED}

Chemotherapy, the use of chemical agents for the treatment of cancer, is generally the adjuvant of choice for metastatic disease when alternative treatment options are limited [17]. A typical chemotherapeutic scheme includes several drugs that possess diverse anticancer mechanisms, such as topoisomerase inhibitors, cytotoxic antibiotics, or spindle poisons. The main aim of combining different agents is to counteract the aberrant molecular events that promote carcinogenesis and tumor progression [18]. However, chemotherapy is impotent in HCC, and most chemotherapeutic agents used alone or in combination are ineffective and relatively toxic to patients [19]. The low efficacy of traditional cytotoxic chemotherapy for managing advanced HCC was previously considered a therapeutic challenge. It is anticipated that enhanced antitumor effects can be achieved through combined application of MTAs and chemotherapy. Furthermore, the doses of MTAs or chemotherapeutic agents can be reduced when given in combination, which might alleviate the adverse effects (AEs) of the drugs [20]. In recent years, several hypotheses related to chemotherapy combined with targeted therapy have been tested in advanced HCC, mainly concentrating on chemotherapy combined with receptor tyrosine kinase inhibitors (RTKIs) or antiangiogenesis clonal antibodies (Table 1).

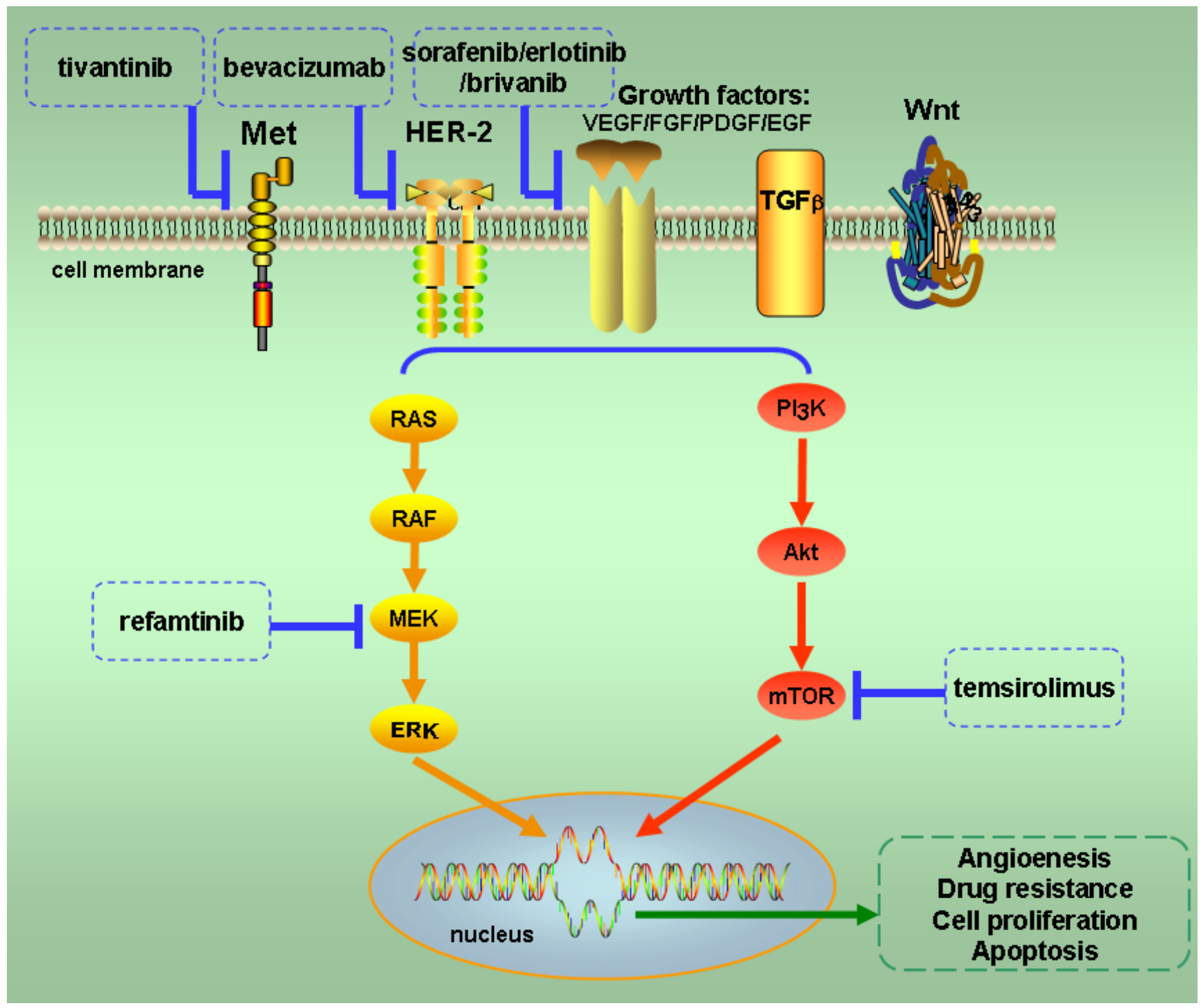

Figure 1: Major pathways of multiple target co-inhibition in advanced hepatocellular carcinoma. Mutations in the RAS/ $\mathrm{RAF} / \mathrm{MEK} / \mathrm{ERK}$ and $\mathrm{PI} 3 \mathrm{~K} / \mathrm{Akt} / \mathrm{mTOR}$ pathways enhance angiogenesis, drug resistance, cell proliferation, and apoptosis to facilitate the growth of cancer. These two pathways are the major targets of strategies involving co-inhibition of dual or multiple targets in the treatment of advanced HCC. The patterns of combined inhibition include dual targets at the level of growth factors and at the level of their downstream pathways. Molecular targeted agents involved in multiple target co-inhibition therapy are listed in this figure. 
Table 2: Clinical trials regarding dual or multiple targeted therapy (with published results).

\begin{tabular}{|c|c|c|c|c|c|c|c|}
\hline Agents & Stage & Patients(n) & Therapeutic shceme & $\begin{array}{l}\text { First or } \\
\text { second line }\end{array}$ & \begin{tabular}{|l|} 
Efficacy \\
(combined \\
therapy \\
monotherapy)
\end{tabular} & $\begin{array}{l}\text { Adverse events } \\
\text { (AEs) }\end{array}$ & Ref \\
\hline $\begin{array}{l}\text { Erlotinib } \\
+ \\
\text { Sorafenib }\end{array}$ & $\begin{array}{l}\text { Phase } \\
3\end{array}$ & 720 & $\begin{array}{l}\text { Sorafenib } 400 \mathrm{mg} \text { bid } \\
\text { po plus erlotinib } 150 \\
\text { mg daily }(n=358) \text { or } \\
\text { sorafenib } 400 \mathrm{mg} \text { bid } \\
\text { po plus placebo } 150 \\
\text { mg daily }(n=362)\end{array}$ & First line & $\begin{array}{l}\text { mOS: } 9.5 \text { vs. } 8.5 \\
\text { months } \\
\text { mTTP: } 3.2 \text { vs. } 4.0 \\
\text { months } \\
\text { ORR: } 6.6 \% \text { vs } \\
3.9 \% \\
\text { DCR: } 43.9 \% \text { vs } \\
\text { 52.5\% }\end{array}$ & $\begin{array}{l}\text { rash/ } \\
\text { desquamation, } \\
\text { anorexia, diarrhea } \\
\text { alopecia and } \\
\text { HFSR. }\end{array}$ & {$[8]$} \\
\hline $\begin{array}{l}\text { Tivantinib } \\
+ \\
\text { Sorafenib } \\
\end{array}$ & $\begin{array}{l}\text { Phase } \\
1\end{array}$ & 20 & $\begin{array}{l}\text { Tivantinib: } 240 \mathrm{mg} \\
\text { bid po plus sorafenib } \\
400 \mathrm{mg} \text { bid po } \\
\end{array}$ & Second line & $\begin{array}{l}\text { ORR: } 10 \% \\
\text { DCR: } 65 \%\end{array}$ & $\begin{array}{l}\text { rash, diarrhea, and } \\
\text { anorexia. }\end{array}$ & {$[9]$} \\
\hline $\begin{array}{l}\text { Brivanib } \\
+ \\
\text { Sorafenib }\end{array}$ & $\begin{array}{l}\text { Phase } \\
3\end{array}$ & 395 & $\begin{array}{l}\text { Brivanib } 800 \mathrm{mg} \\
\text { po daily plus best } \\
\text { supportive care } \\
\text { (BSC) }(n=263) \text { vs } \\
\text { placebo plus BSC ( } n \\
=132) .\end{array}$ & Second line & $\begin{array}{l}\text { mOS: } 9.4 \text { vs. } 8.2 \\
\text { months } \\
\text { mTTP: } 4.2 \text { vs. } 2.7 \\
\text { months } \\
\text { ORR: } 10 \% \text { vs. } 2 \% \\
\text { DCR: } 61 \% \text { vs } \\
\text { 40\%. } \\
\end{array}$ & \begin{tabular}{|l|} 
hypertension, \\
fatigue, \\
hyponatremia, \\
decreased appetite, \\
asthenia, diarrhea, \\
increased AST and \\
ALT. \\
\end{tabular} & {$[10]$} \\
\hline $\begin{array}{l}\text { Bevacizumab } \\
+ \\
\text { Erlotinib }\end{array}$ & $\begin{array}{l}\text { Phase } \\
2\end{array}$ & 51 & $\begin{array}{l}\text { Bevacizumab: } 5 \mathrm{mg} / \\
\mathrm{kg} \text { i.v. plus erlotinib } \\
150 \mathrm{mg} \text { po daily }\end{array}$ & First line & $\begin{array}{l}\text { mPFS: } 2.9 \text { months } \\
\text { mOS: } 10.7 \\
\text { months. }\end{array}$ & $\begin{array}{l}\text { rash, acne, } \\
\text { diarrhea and } \\
\text { gastrointestinal } \\
\text { bleeding. } \\
\end{array}$ & {$[11]$} \\
\hline $\begin{array}{l}\text { Bevacizumab } \\
+ \\
\text { Erlotinib }\end{array}$ & $\begin{array}{l}\text { Phase } \\
2\end{array}$ & 40 & $\begin{array}{l}\text { Bevacizumab: } 10 \mathrm{mg} / \\
\text { kg i.v. plus erlotinib } \\
150 \mathrm{mg} \text { po daily. }\end{array}$ & First line & $\begin{array}{l}\text { mPFS: } 9.0 \text { months } \\
\text { mOS: } 15.7 \text { months }\end{array}$ & \begin{tabular}{|l|} 
fatigue, \\
hypertension, \\
diarrhea, elevated \\
transaminases, \\
gastrointestinal \\
hemorrhage, \\
wound infection \\
thrombocytopenia. \\
\end{tabular} & [12] \\
\hline $\begin{array}{l}\text { Bevacizumab } \\
+ \\
\text { Temsirolimus }\end{array}$ & $\begin{array}{l}\text { Phase } \\
2\end{array}$ & 28 & $\begin{array}{l}\text { Temsirolimus } 25 \mathrm{mg} \\
\text { i.v. plus } \\
\text { bevacizumab } 10 \mathrm{mg} / \\
\mathrm{kg} \text { i.v. }\end{array}$ & First line & $\begin{array}{l}\text { mPFS: } 7 \text { months } \\
\text { mOS: } 14 \text { months } \\
\text { ORR: } 19 \%\end{array}$ & $\begin{array}{l}\text { cytopenias, } \\
\text { fatigue, mucositis, } \\
\text { diarrhea and mild } \\
\text { bleeds. } \\
\end{array}$ & {$[13]$} \\
\hline $\begin{array}{l}\text { Refametinib } \\
+ \\
\text { Sorafenib }\end{array}$ & $\begin{array}{l}\text { Phase } \\
2\end{array}$ & 95 & $\begin{array}{l}\text { Refametinib } 50 \\
\text { mg bid po plus } \\
\text { sorafenib } 200 \mathrm{mg} \\
\text { (morning)/400 mg } \\
\text { (evening) bid po }\end{array}$ & First line & $\begin{array}{l}\text { DCR: } 44.8 \% \\
\text { mTTP: } 122 \text { days } \\
\text { mOS: } 290 \text { days }\end{array}$ & $\begin{array}{l}\text { diarrhea, rash, } \\
\text { aspartate } \\
\text { aminotransferase } \\
\text { elevation, } \\
\text { vomiting and } \\
\text { nausea. } \\
\end{array}$ & [14] \\
\hline $\begin{array}{l}\text { Temsirolimus } \\
+ \\
\text { Sorafenib }\end{array}$ & $\begin{array}{l}\text { Phase } \\
1\end{array}$ & 25 & $\begin{array}{l}\text { Temsirolimus } 10 \\
\text { mg weekly po plus } \\
\text { sorafenib } 200 \mathrm{mg} \text { bid } \\
\text { po. }\end{array}$ & First line & DCR: $68 \%$ & $\begin{array}{l}\text { hypophosphatemia, } \\
\text { infection, } \\
\text { thrombocytopenia, } \\
\text { HFSR and fatigue. }\end{array}$ & {$[15]$} \\
\hline
\end{tabular}

Abbreviations: AST: Aspartate Transaminase; ALT: Alanine Aminotransferase; HFSR: Hand-Foot Syndrome Reaction.

\section{RTKIs plus chemotherapy}

Receptor tyrosine kinases (RTKs) are the highaffinity cell surface receptors for many polypeptide growth factors, cytokines and hormones and are essential for cell signal transduction of normal cells and cancer cells [21]. Targeted agents that inhibit RTKs account for a large percentage of the MTAs used in HCC. To date, the therapeutic strategy involving RTKIs and chemotherapy to treat $\mathrm{HCC}$ is confined to the use of sorafenib or erlotinib plus cytotoxic agents. The most promising results have been presented for sorafenib plus doxorubicin [22]. Doxorubicin, which functions by intercalating into the DNA, has a definite effect in repressing the progression of $\mathrm{HCC}$, but this is accompanied by various AEs. Among these AEs, the most serious is life-threatening heart damage [23]. When doxorubicin is combined with sorafenib, patients may receive additional clinical benefits. Abou-Alfa et al. evaluated the efficacy and safety of combination treatment with doxorubicin and sorafenib [22]. In this double-blind controlled phase II study, 96 
patients with advanced $\mathrm{HCC}$ were randomly assigned to receive doxorubicin $\left(60 \mathrm{mg} / \mathrm{m}^{2}\right)$ plus sorafenib or placebo (400 mg twice daily). The outcome from this trial was promising, and showed significant prolongation of median time to progression (TTP), OS, and PFS compared with the control arm (doxorubicin plus placebo). Notwithstanding the absence of a comparative sorafenib standard group in the research, this trial illustrates that sorafenib plus doxorubicin may contribute to treating advanced HCC. In addition, relevant clinical research is ongoing in a phase III trial (NCT01015833) with a larger sample size and a sorafenib-controlled arm. This therapeutic setting is rational because anthracycline antibiotics such as doxorubicin have been demonstrated to inhibit angiogenesis [24] and thus may perform complementary inhibitory functions when administered in combination with sorafenib. Moreover, suppression of the RAS/RAF/MEK/ERK pathway can partly alleviate drug resistance in malignant tumors [25]. Others combinations (Table 1) involving erlotinib plus docetaxel or erlotinib plus gemcitabine and oxaliplatin show insignificant antitumor outcomes in HCC and biliary cancer [26]. Intriguingly, the subset of patients with negative/low E-cadherin expression or K-Ras mutation might gain valid tumor control. Considering that the specific target of erlotinib is the epidermal growth factor receptor (EGFR) [27], this phenomenon hints that increased clinical benefits of RTKIs plus chemotherapy might be achieved through precise selection of eligible patients.

\section{Anti-angiogenesis clonal antibodies plus chemotherapy}

Clonal antibodies targeting angiogenesis ligands or receptors have been widely applied to treat various kinds of cancer [28]. Because vascular growth is one of the essential factors in the occurrence and development of $\mathrm{HCC}$, the role of anti-angiogenesis agents in HCC therapy is quite significant [29]. However, anti-angiogenesis

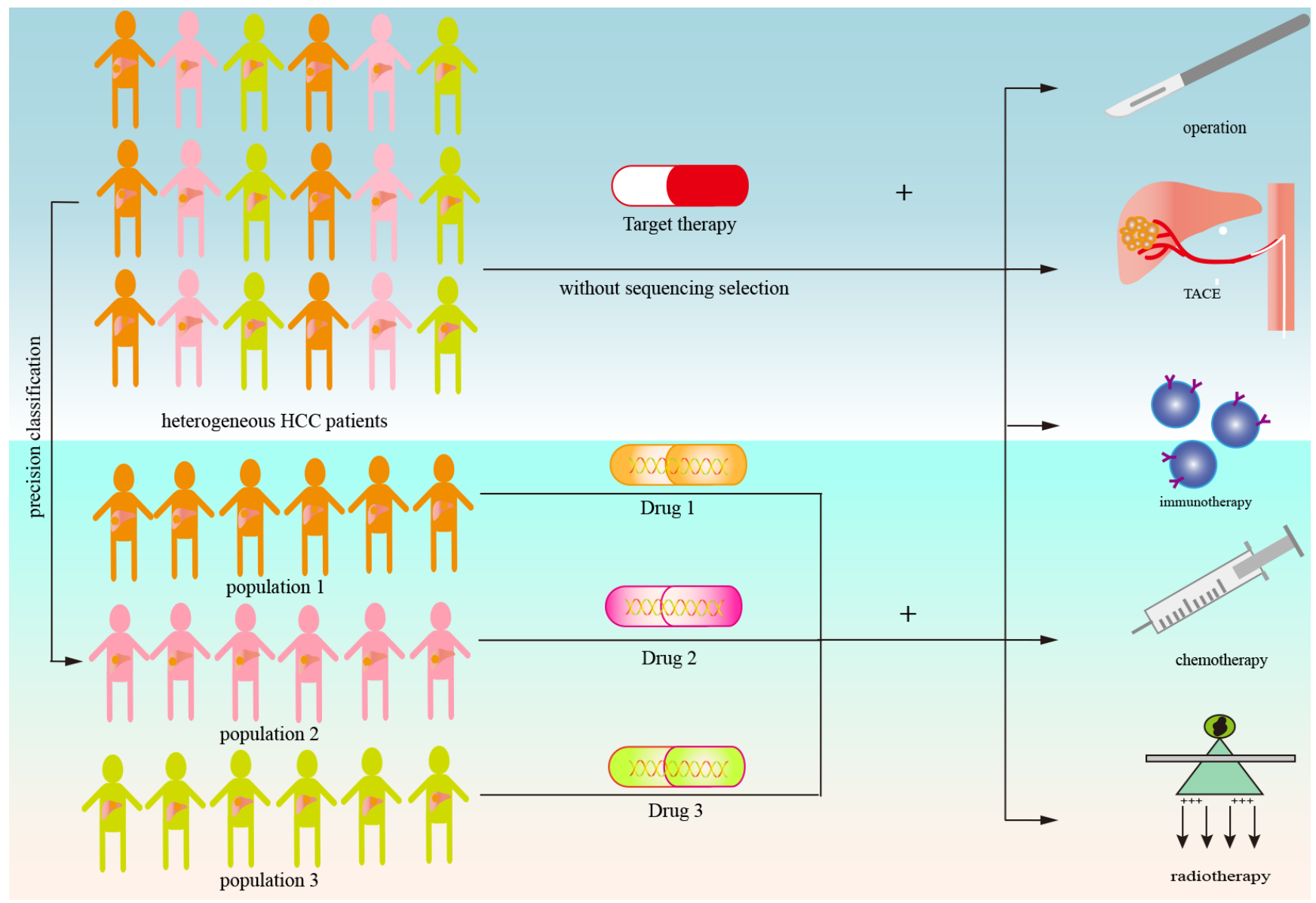

Figure 2: Schematic of combination treatment based on targeted therapy in advanced hepatocellular carcinoma. In patients with advanced HCC, combination treatment based on targeted therapy involves molecular targeted agents combined with other modalities such as surgery, TACE, immunotherapy, chemotherapy, or radiotherapy. The lack of precise target population selection may be the primary reason for limited cancer control using these strategies. Treatment will become more precise and effective through effective screening of patients with potential benefits. This may be achieved by genome sequencing to identify therapeutic targets or by more reliable molecular classification of the tumor. 
Table 3: Clinical trials regarding TACE combine with targeted therapy (with published results).

\begin{tabular}{|c|c|c|c|c|c|c|c|}
\hline Agents & Stage & patients(n) & Therapeutic scheme & \begin{tabular}{|l|} 
First or \\
second \\
line \\
\end{tabular} & \begin{tabular}{|l|} 
Efficacy (combined \\
therapy vs \\
monotherapy) \\
\end{tabular} & $\begin{array}{l}\text { Adverse events } \\
\text { (AEs) }\end{array}$ & Ref \\
\hline $\begin{array}{l}\text { Sorafenib } \\
+ \\
\text { TACE }\end{array}$ & $\begin{array}{l}\text { Phase } \\
3\end{array}$ & 458 & $\begin{array}{l}\text { Sorafenib } 400 \text { ( } n= \\
229) \text { mg bid po or } \\
\text { placebo }(n=227) \text { po } \\
\text { after } 1-2 \text { TACE }\end{array}$ & First line & $\begin{array}{l}\text { mTTP: } 5.4 \text { vs. } 3.7 \\
\text { months } \\
\text { 3-months PFR: } \\
65.0 \% \text { vs } 58.7 \% \\
\text { mOS: } 29.7 \text { months } \\
\text { vs. NR }\end{array}$ & $\begin{array}{l}\text { HFSR, elevated } \\
\text { lipase, alopecia and } \\
\text { rash/desquamation. }\end{array}$ & {$[16]$} \\
\hline $\begin{array}{l}\text { Sorafenib } \\
+ \\
\text { TACE }\end{array}$ & $\begin{array}{l}\text { Phase } \\
2\end{array}$ & 304 & $\begin{array}{l}\text { Sorafenib } 400 \mathrm{mg} \text { bid } \\
\text { po }(n=82)+\text { TACE vs } \\
\text { TACE alone }(n=222)\end{array}$ & First line & $\begin{array}{l}\text { mTTP: } 6.3 \text { vs } 4.3 \\
\text { months } \\
\text { mOS: } 7.5 \text { vs } 5.1 \\
\text { months } \\
\text { DCR: } 58.5 \% \text { vs } \\
\text { 44.5\% }\end{array}$ & $\begin{array}{l}\text { hand-foot skin } \\
\text { reaction, alopecia } \\
\text { and diarrhea, } \\
\text { gastrointestinal } \\
\text { bleeding, } \\
\text { hyperbilirubinemia } \\
\text { and hepatic } \\
\text { encephalopathy. }\end{array}$ & {$[17]$} \\
\hline $\begin{array}{l}\text { Sorafenib } \\
+ \\
\text { TACE }\end{array}$ & $\begin{array}{l}\text { Phase } \\
2\end{array}$ & 80 & $\begin{array}{l}\text { Sorafenib } 400(n=31) \\
\text { mg bid po or placebo } \\
(n=31) \text { po after TACE }\end{array}$ & First line & $\begin{array}{l}\text { mTTP: } 9.2 \text { vs. } 4.9 \\
\text { months }\end{array}$ & $\begin{array}{l}\text { anorexia, diarrhea, } \\
\text { fatigue, hand-foot } \\
\text { skin reaction, } \\
\text { hematological } \\
\text { event, nausea, rash/ } \\
\text { desquamation. } \\
\end{array}$ & {$[18]$} \\
\hline $\begin{array}{l}\text { Sorafenib } \\
+ \\
\text { TACE }\end{array}$ & $\begin{array}{l}\text { Phase } \\
2\end{array}$ & 43 & $\begin{array}{l}\text { Sorafenib: starting } \\
\text { dose of } 200 \text { mg bid po } \\
\text { increased to } 400 \mathrm{mg} \\
\text { bid in the majority of } \\
\text { patients }(n=13) \text {, or } \\
\text { placebo }(n=30) \text { after } \\
\text { TACE }\end{array}$ & First line & $\begin{array}{l}\text { mOS: } 20.6 \text { vs } 13.8 \\
\text { months; }\end{array}$ & $\begin{array}{l}\text { pain, nausea, } \\
\text { vomiting and mild } \\
\text { elevation of liver } \\
\text { enzymes. }\end{array}$ & {$[19]$} \\
\hline $\begin{array}{l}\text { Sorafenib } \\
+ \\
\text { TACE }\end{array}$ & $\begin{array}{l}\text { Phase } \\
2\end{array}$ & 355 & $\begin{array}{l}\text { Sorafenib } 400 \mathrm{mg} \text { bid } \\
\text { po plus TACE }(n= \\
164) \text { vs sorafenib alone } \\
(n=191)\end{array}$ & First line & $\begin{array}{l}\text { mTTP: } 2.5 \text { vs } 2.1 \\
\text { months; } \\
\text { mOS: } 8.9 \text { vs } 5.9 \\
\text { months. }\end{array}$ & $\begin{array}{l}\text { hand-foot skin } \\
\text { reaction }\end{array}$ & {$[20]$} \\
\hline $\begin{array}{l}\text { Sorafenib } \\
+ \\
\text { TACE } \\
\end{array}$ & $\begin{array}{l}\text { Phase } \\
2\end{array}$ & 45 & $\begin{array}{l}\text { Sorafenib } 200 \mathrm{mg} \text { bid } \\
\text { po plus TACE }\end{array}$ & First line & $\begin{array}{l}\text { mOS: } 27 \text { vs. } 17 \\
\text { months }\end{array}$ & $\begin{array}{l}\text { hand-foot skin } \\
\text { reaction, rash and } \\
\text { diarrhea. }\end{array}$ & {$[21]$} \\
\hline $\begin{array}{l}\text { Bevacizumab } \\
+ \\
\text { TACE }\end{array}$ & $\begin{array}{l}\text { Phase } \\
2\end{array}$ & 32 & $\begin{array}{l}\text { Bevacizumab (5 mg/ } \\
\mathrm{kg})(n=16) \text { or placebo } \\
(n=16)\end{array}$ & First line & $\begin{array}{l}\text { mTTP: } 7.2 \text { vs. } 11.7 \\
\text { months } \\
\text { mOS: } 5.3 \text { vs } 13.7 \\
\text { months }\end{array}$ & $\begin{array}{l}\text { severe bleeding, } \\
\text { vascular, and septic } \\
\text { events; right heart } \\
\text { dilatation, anorexia, } \\
\text { fatigue, or alopecia } \\
\text { were low-grade } \\
\text { events }\end{array}$ & {$[22]$} \\
\hline $\begin{array}{l}\text { Bevacizumab } \\
+ \\
\text { TACE }\end{array}$ & $\begin{array}{l}\text { Phase } \\
2\end{array}$ & 30 & $\begin{array}{l}\text { Bevacizumab } 10 \mathrm{mg} / \\
\mathrm{kg} \text { IV }(n=15) \text { or } \\
\text { placebo }(n=15) .\end{array}$ & First line & $\begin{array}{l}\text { mOS: } 49 \text { vs. } 61 \\
\text { months } \\
\text { 16-weeks PFS rate: } \\
79 \% \text { vs } 19 \% .\end{array}$ & $\begin{array}{l}\text { elevated } \\
\text { transaminases, pain, } \\
\text { pyrexia, nausea/ } \\
\text { vomiting, and } \\
\text { fatigue. } \\
\end{array}$ & {$[23]$} \\
\hline $\begin{array}{l}\text { Sunitinib } \\
+ \\
\text { TACE }\end{array}$ & $\begin{array}{l}\text { Phase } \\
2\end{array}$ & 103 & $\begin{array}{l}\text { Sunitinib }(n=38) 37.5 \\
\text { mg po daily or placebo } \\
(n=65) \text { after TACE }\end{array}$ & First line & $\begin{array}{l}\text { mOS: } 8.8 \text { vs } 6.3 \\
\text { months } \\
\text { mTTP: } 3.9 \text { vs } 2.5 \\
\text { months }\end{array}$ & $\begin{array}{l}\text { hrombocytopenia, } \\
\text { fatigue, leukopenia, } \\
\text { and anemia. upper } \\
\text { gastrointestinal } \\
\text { bleeding, hepatic } \\
\text { encephalopathy, and } \\
\text { hyperbilirubinemia. }\end{array}$ & {$[24]$} \\
\hline $\begin{array}{l}\text { Sunitinib } \\
+ \\
\text { TACE }\end{array}$ & $\begin{array}{l}\text { Phase } \\
2\end{array}$ & 16 & $\begin{array}{l}\text { Sunitinib } 37.5 \mathrm{mg} \text { po } \\
\text { daily after TACE }\end{array}$ & First line & $\begin{array}{l}\text { mPFS: } 8 \text { months } \\
\text { mOS: } 14.9 \text { months } \\
\text { DCR: } 81 \% .\end{array}$ & $\begin{array}{l}\text { thrombocytopenia, } \\
\text { increase of } \\
\text { amylase/lipase, } \\
\text { lymphopenia, and } \\
\text { fatigue. }\end{array}$ & {$[25]$} \\
\hline
\end{tabular}


antibodies alone often show an inadequate anticancer effect in the treatment of patients with advanced HCC [30]. For instance, use of bevacizumab, a humanized recombinant monoclonal antibody that binds all isoforms of circulating VEGF-A, has been validated in many solid tumors. Monotherapy using bevacizumab in patients with advanced HCC, however, merely achieves a partial response [31]. When bevacizumab is combined with chemotherapeutic agents, it may strengthen chemotherapy activity and enhance chemosensitivity [32, 33] despite its direct antiangiogenic effects. The combination of bevacizumab with chemotherapy has been shown to provide clinical benefits in patients with breast, lung, and colorectal cancer and has been tested in patients with $\mathrm{HCC}$ [34]. For example, the GEMOX-B regimen containing gemcitabine, oxaliplatin, and bevacizumab demonstrated moderate antitumor activity and good tolerability in patients with unresectable or metastatic HCC [35]. Other regimens of combination therapy, such as capecitabine plus bevacizumab with or without oxaliplatin, have also been tested with outcomes similar to those of GEMOX-B [36, 37]. Moreover, metronomic capecitabine was presented as a potential second-line treatment for HCC after development of sorafenib resistance in a retrospective study. The disease control rate (DCR) was 23\% and median OS reached 8 months in this study [38]. These results demonstrate that combined application of bevacizumab and chemotherapeutic agents could be well tolerated and may open up alternative therapeutic options for treating advanced HCC.

Another antitumor clonal antibody, cetuximab, a monoclonal antibody with anticancer biological activity through inhibition of EGFR, has been demonstrated to possess enhanced effectiveness in combination with chemotherapy in both colorectal cancer and HCC [39, 40]. Several lines of evidence have proved that blockade of the EGFR pathway can increase the response rate of radiotherapy or chemotherapy in EGFR-activated carcinomas [41]. Therefore, potent suppression of angiogenesis by combination treatment with chemotherapy and targeted therapy may be an attractive option for patients with advanced HCC.

\section{CO-INHIBITION OF DUAL OR MULTIPLE TARGETS}

Although many MTAs have been used to treat HCC, most of these drugs have limited effectiveness in controlling the progression of tumors [14] and the real clinical benefits of targeted therapy are inadequate [42]. Obstacles such as drug resistance, limited efficacy, relapse, and recrudescence hamper the development and clinical utilization of Ms in HCC [43]. Drawing lessons from combination chemotherapy regimens, the concept of co-inhibition of multiple targets or pathways has been proposed in an attempt to enhance the antitumor effect by simultaneously inhibiting multiple targets or pathways [44].

\section{Rationality of multitarget therapeutics}

Numerous investigations concerning the mechanisms of resistance to MTAs have been conducted in recent years. Based on our current understanding, the mechanism of targeted therapeutic resistance is attributable to the complex systems of cell signal transduction and pathway networks [45]. The mainstream theory of targeted therapeutic resistance principally covers three aspects: (1) pathway redundancy, which is the ability of a signaling pathway to maintain an activated status even under inhibition by a targeted therapy [46]; (2) escape pathways, in which cell signal transduction can recruit an alternate signaling pathway through a cross-talk effect to escape attack on a targeted therapy [47]; (3) pathway reactivation, referring to the ability of a cell to reactivate the signaling pathway via downstream mutations despite inhibitory therapy [48]. In addition, heterogeneity is a considerable factor in tumor progression and drug resistance. Increasingly, studies have demonstrated the existence of abundant intra-tumor and inter-tumor heterogeneity [49-51]. Moreover, by applying the method of next-generation sequencing (NGS) polyclonality has been confirmed in multicentric $\mathrm{HCC}[52,53]$, revealing independent tumorigenic occurrence. For these reasons, the strategy of suppressing only one target or pathway is no longer considered viable for treating HCC. Thus, to achieve greater efficacy in targeted therapy, inhibiting more than one target simultaneously may become a feasible approach to curb carcinogenesis as well as tumor progression. The concept of combining molecular target agents has been proposed and put into practice during the last few years [54], and several relevant clinical trials have been carried out for HCC. Here we categorize these trials as (1) combination blockade at the level of growth factor receptors (GFRs) and (2) combination blockade at the level of downstream pathways (Figure 1).

\section{Combination blockade at the level of GFRs}

The balance between proangiogenic and antiangiogenic factors is crucial as carcinogenesis can be triggered when this balance is disturbed [55]. In addition, cancer cells, endothelial cells, and pericytes together change the microenvironment of the tumor [56]. Consequently, many GFRs, including EGFR, vascular endothelial growth factor receptor (VEGFR), plateletderived growth factor receptor (PDGFR), c-mesenchymalepithelial transition factor-1 (c-Met), and fibroblast growth factor receptor (FGFR), have been shown to 
Table 4: Other combination regimens based on targeted therapy in hepatocellular carcinoma (with published results).

\begin{tabular}{|c|c|c|c|c|c|c|c|}
\hline Agents & Stage & Patients(n) & Therapeutic scheme & $\begin{array}{l}\text { First or } \\
\text { second } \\
\text { line }\end{array}$ & $\begin{array}{l}\text { Efficacy (combined } \\
\text { therapy } \\
\text { monotherapy) } \\
\end{array}$ & $\begin{array}{l}\text { Adverse events } \\
\text { (AEs) }\end{array}$ & Ref \\
\hline $\begin{array}{l}\text { Radiofrequency } \\
\text { ablation (RFA) } \\
+ \\
\text { Sorafenib }\end{array}$ & $\begin{array}{l}\text { Phase } \\
2\end{array}$ & 128 & $\begin{array}{l}\text { Radiofrequency } \\
\text { ablation plus } \\
\text { sorafenib ( } 400 \mathrm{mg} \\
\text { bid) }(n=64) \text { vs } \\
\text { radiofrequency } \\
\text { ablation alone ( } n= \\
64)\end{array}$ & Both & $\begin{array}{l}\text { mOS: } 161.8 \text { vs } 118.6 \\
\text { weeks. } \\
\text { The } 1-, 2 \text { - and } 3- \\
\text { year cumulative } \\
\text { incidences: } 62.8 \% \text {, } \\
85.4 \% \text { and } 92.7 \% \text { vs } \\
40.5 \%, 62.9 \% \text { and } \\
74.5 \% \text {. }\end{array}$ & $\begin{array}{l}\text { gastrointestinal } \\
\text { bleeding, pleural } \\
\text { effusion requiring } \\
\text { drainage, mild } \\
\text { or moderate } \\
\text { increase in body } \\
\text { temperature. }\end{array}$ & {$[87]$} \\
\hline $\begin{array}{l}\text { Radiofrequency } \\
\text { ablation (RFA) } \\
+ \\
\text { Sorafenib }\end{array}$ & $\begin{array}{l}\text { Phase } \\
2\end{array}$ & 45 & $\begin{array}{l}\text { Radiofrequency } \\
\text { ablation plus } \\
\text { sorafenib }(400 \mathrm{mg} \\
\text { bid) }(n=15) \text { vs } \\
\text { radiofrequency } \\
\text { ablation alone }(n= \\
30)\end{array}$ & Both & $\begin{array}{l}\text { RFA-induced ablated } \\
\text { area: } 46.3 \mathrm{~mm} \pm 10.3 \\
\text { and } 33.0 \mathrm{~mm} \pm 6.9 v s \\
32.9 \mathrm{~mm} \pm 7.6 \text { and } \\
25.6 \mathrm{~mm} \pm 5.7\end{array}$ & $\begin{array}{l}\text { serum asparatate } \\
\text { aminotransferase } \\
\text { concentration } \\
\text { transient } \\
\text { increases, } \\
\text { handfoot skin } \\
\text { reaction. }\end{array}$ & {$[116]$} \\
\hline $\begin{array}{l}\text { Radiofrequency } \\
\text { ablation (RFA) } \\
+ \\
\text { Sorafenib }\end{array}$ & $\begin{array}{l}\text { Phase } \\
2\end{array}$ & 62 & $\begin{array}{l}\text { Radiofrequency } \\
\text { ablation plus } \\
\text { sorafenib (400mg } \\
\text { bid) }(n=30) \text { vs } \\
\text { radiofrequency } \\
\text { ablation alone ( } n= \\
32)\end{array}$ & First line & $\begin{array}{l}\text { recurrent rate: } 56.7 \% \\
\text { vs } 87.5 \% \text {; } \\
\text { mTTP: } 17.0 \text { vs } 6.1 \\
\text { months; }\end{array}$ & $\begin{array}{l}\text { hand-foot } \\
\text { skin reactions, } \\
\text { diarrhea, fatigue, } \\
\text { alopecia and } \\
\text { hypertension. }\end{array}$ & {$[86]$} \\
\hline
\end{tabular}

be upregulated in $\mathrm{HCC}$ at the level of protein and gene expression [57]. Additionally, most of these GFRs belong to the family of RTKs. Because of the important role of RTKs in the initiation, progression, and maintenance of carcinomas, it is necessary to suppress RTKs adequately by therapy [58].

As mono-RTK targeted therapy shows low efficacy in the treatment of $\mathrm{HCC}$, multitarget co-inhibition should be explored (Table 2). Although there is no evidence of crosstalk between EGFR and VEGF, a large percentage of clinical trials on HCC utilize EGFR-VEGF combination blockade for co-inhibition of these GFRs. This probably reflects the limited availability of approved clinical targeted drugs [59]. The outcomes in actual clinical practice varied among different research groups, so it is inappropriate to draw conclusions on the efficacy of this regimen of multitarget inhibition. For instance, Thomas et al. reported the outcome of a phase II clinical trial combining bevacizumab and erlotinib in patients with advanced HCC [60]. They studied 40 patients with advanced HCC and concluded that the combination of bevacizumab and erlotinib showed valuable antitumor activity in addition to being well tolerated. Another clinical trial conducted in Asian patients showed a similar outcome [61]. In this single-arm clinical trial for 51 participants who received erlotinib plus bevacizumab, the median PFS was 2.9 months and the median OS was 10.7 months; furthermore, grade $3 / 4$ adverse events were infrequent and tolerable. These two trials demonstrate to a certain degree that use of bevacizumab plus erlotinib is effective for advanced HCC. Erlotinib, an EGFR inhibitor, has shown promising effects in alleviating fibrogenesis and controlling angiogenesis [62], whereas bevacizumab is an angiogenesis inhibitor. Although these two drugs each possess limited antitumor effects in advanced HCC, combined application shows encouraging outcomes.

As the most efficient agent used in monotherapy, sorafenib improves OS and PFS in patients with advanced $\mathrm{HCC}$; however, its efficacy is limited and most patients ultimately die from the disease [63]. Therefore, researchers have investigated whether superior antitumor function could be accomplished by using sorafenib combined with other molecular agents targeting growth receptor factors. Many clinical explorations have been carried out using combinations such as brivanib plus sorafenib, erlotinib plus sorafenib, ramucirumab plus sorafenib, and regorafenib plus sorafenib (Table 2); however, the results of these clinical investigations are disappointing. For example, Zhu et al. showed no value from adding erlotinib to sorafenib in a comparison of the clinical benefit of sorafenib plus either erlotinib or placebo [64]. Llovet et al. evaluated 395 patients with advanced HCC who progressed during or after treatment or were resistant to sorafenib [65]. These patients were randomly assigned (2:1) to receive brivanib (a RTK inhibitor of VEGF and FGF) $800 \mathrm{mg}$ orally daily plus best supportive care (BSC) or placebo plus BSC. The clinical benefits were similar between the two groups, indicating that sorafenibbased combination therapy showed no superiority over sorafenib monotherapy. Based on the outcomes of these clinical trials, it is not currently recommended to combine sorafenib with other targeted agents to treat advanced HCC. 


\section{Combination blockade at the level of the downstream pathway}

Cell signal pathway reactivation, which is induced by mutation of downstream components, is the primary mechanism of resistance to MTAs [45]. In HCC, both the RAS/RAF/MEK/ERK pathway and the PI3K/Akt/mTOR pathway can be activated by gain-of-function mutations or overexpression of GFRs [66]. Moreover, either the RAS/RAF/MEK/ERK or PI3K/Akt/mTOR pathway has been frequently identified as the mutation hotspot of hepatocarcinogenesis in cases of resistance to targeted therapy (Figure 1) [67]. The increased antitumor efficiency of combination blockade at the level of the downstream pathway was confirmed in preclinical studies. Rudalska et al. used shRNA screening in a mouse model of HCC to identify Mapk14 (p38 $\alpha$ ) as one of the targets of sorafenib therapy resistance [68]. They demonstrated that elevated Mapk14-Atf2 signaling is a poor prognostic factor in sorafenib therapy of human HCC, which may translate to a promising novel approach to identify HCC patients with sorafenib resistance. In addition, the synthetic lethality of sorafenib plus a Mek inhibitor was verified in vitro using a medullary thyroid carcinoma cell line [69].

Based on these findings, Lim et al. reported the outcome of combination therapy with refametinib (a MEK inhibitor) plus sorafenib for Asian patients with advanced HCC [70]. In the 70 patients who received the study treatment, DCR was $44.8 \%$ and median TTP and OS were reached after 122 and 290 days, respectively. These outcomes seem to suggest that blockade upstream and downstream of a certain pathway both deserve further investigation. However, the toxicity produced by multitarget inhibition should be considered. Shimizu et al. performed retrospective research to evaluate the clinical effects and tolerability of a dual-targeting method involving the $\mathrm{PI} 3 \mathrm{~K} / \mathrm{AKT} / \mathrm{mTOR}$ and RAS/MEK/ERK pathways [71]. They reviewed 236 patients with advanced solid tumors who received treatments targeting the PI3K/ AKT/mTOR and/or RAS/MEK/ERK pathways. Through deliberated assessment and comparisons they showed that although dual-pathway inhibition potentially showed promising efficacy compared with suppression of a single pathway, greater toxicity was the main obstacle to this therapeutic strategy. The rates of agent-related AEs greater than grade 3 were significantly higher in the dual-pathway group than with single-pathway inhibition $(53.9 \%$ vs. $18.1 \%, P<0.001)$. Given these results, for now clinicians are advised to be cautious with regard to combination blockade of multiple targets or pathways.

\section{TARGETED THERAPY COMBINED WITH TRANSCATHETER ARTERIAL CHEMOEMBOLIZATION (TACE)}

Patients with advanced HCC with poor liver function and large tumor size have limited treatment options. TACE, a local treatment, is the first approach to provide a survival benefit in unresectable HCC [72]. TACE can be performed with diverse chemotherapeutic agents through infusion directly into the vessels supplying the tumor while blocking these vessels with a specific embolization material [73]. For a significant survival advantage, it is appropriate to combine TACE with targeted therapy in the treatment of advanced HCC [74].

It is reasonable to consider the combination of a local treatment (such as TACE) and antiangiogenic therapy (such as MTAs). First, increased levels of angiogenesis factors such as VEGF and angiopoietin can be triggered by the extensive ischemic necrosis caused by TACE [75]. Additionally, hypoxia induced by arterial embolization can promote the proliferation of tumor cells in addition to inhibiting apoptosis [76]. Hypoxia can also concurrently stimulate the production of several neo-angiogenesis factors including VEGF and IGF-2 [77]. Since angiogenesis plays a major role in tumor progression, as well as adaption and recurrence, a synergistic effect can be achieved when TACE is combined with targeted therapy aimed at upregulation of VEGF or other angiogenesis factors [78].

Several preclinical and clinical studies have shown that administration of multikinase inhibitors before or after TACE may target lesions distal to the TACE site, extend time to recurrence or progression, and improve survival (Table 3) [79]. Studies in laboratory models proved that the therapeutic efficacy of TACE was enhanced by antiangiogenic therapy through a recombinant adenoassociated virus vector encoding murine angiostatin [80]. In addition, a meta-analysis reported by Zhang et al. confirmed that OS, TTP, and overall response rate could be improved by combination therapy with TACE plus sorafenib in patients with intermediate or advanced HCC [81]. A worldwide prospective non-interventional study evaluating distinct patient subsets that compared the outcomes of sorafenib after TACE $(n=158)$ and sorafenib monotherapy $(n=29)$ confirmed that sorafenib can be used safely in combination with TACE [82]. Another attractive clinical trial, SPACE, assessed the efficacy of sorafenib plus TACE with doxorubicin-eluting beads (DEB-TACE) for intermediate-stage HCC. Its latest data revealed negative results for the improvement of TTP and clinical benefits in the combined therapy arm [83]. In this trial, 307 patients were randomly assigned to receive DEB-TACE plus sorafenib $(n=154)$ or placebo. The median OS was not reached, and TTP between each arm was similar, although DCR differed (89.2\% for DEB- 
TACE plus sorafenib vs. $76.1 \%$ for DEB-TACE plus placebo). Interestingly, a longer median TTP was observed in the subgroup of Asian patients, which may be explained by the specific etiology of HCC. Additionally, brivanib, a dual inhibitor of VEGF and FGF signaling that suppresses the process of angiogenesis, was unable to improve OS when used as an adjuvant therapy to TACE [84].

Local treatment with TACE in patients with intermediate or advanced HCC in combination with antiangiogenesis targeted therapy appears to be a feasible strategy. This approach has been demonstrated to be well tolerated; however, the efficacy of this type of combination should be further verified.

\section{TARGETED THERAPY COMBINED WITH OTHER TREATMENTS}

Other treatments for advanced HCC, such as radiotherapy, PEI, immunotherapy, and even surgical resection, have also been attempted in combination with targeted therapy. Some combinations have shown promising outcomes. For example, enhanced radiosensitivity could be achieved through combined targeted inhibition of Sonic Hedgehog (SHH) [85]. Combination therapy with sorafenib and radiofrequency ablation (RFA) was associated with a better OS and a lower incidence of post-RFA recurrence compared with RFA alone (Table 4). However, this has only been confirmed in a small-sample randomized controlled trial [86] and in retrospective studies [87].

For patients who obtain apparent tumor remission during ongoing targeted therapy, the options for further therapy should be evaluated. Curtit et al. reported a case in which a potential benefit was gained from pre-surgery targeted therapy. A 56-year-old man with advanced HCC in the context of a long history of hepatitis C-related cirrhosis showed obvious tumor suppression after 6 months of sorafenib treatment. The size of the liver tumor was reduced, providing the opportunity to perform tumor resection. Pathologic examination indicated that complete histologic response was achieved [88]. It is worth verifying whether targeted therapy could be used as an adjuvant treatment before surgical excision or radiotherapy in advanced $\mathrm{HCC}$.

Although the outcomes of single MTAs applied to date in the treatment of advanced HCC are depressing, improved therapeutic effect might be attained for novel targeted agents such as p53 mutation, which is one of the most frequent driver mutations in patients with HCC [89]. Gene therapy targeting p53 in liver cancer revealed encouraging activity in inhibiting carcinogenesis although MTAs that inhibit p53 are currently not available $[90,91]$. Li [90] demonstrated a synergetic increase in the therapeutic efficacy of trans-arterial embolization (TAE) and targeted gene therapy through application of a polyplex formed by surface modified nHAP and p53- expressing plasmid as a gene vector in hepatoma-targeted TAE gene therapy. Moreover, targeted overexpression of tBid or BikDD has been validated as a method to reduce tumor growth [92-94], especially when combined with chemotherapy $[95,96]$. Bik is a BH3-only protein of the $\mathrm{Bcl}-2$ family that promotes apoptosis and $\mathrm{tBid}(\mathrm{p} 15)$ is one of the fragments of Bid released in response to apoptotic stimuli. BikDD is a Bik mutant containing changes in T33D and S35D that mimic phosphorylation at these two residues, thus enhancing binding affinity with the antiapoptotic proteins Bcl-XL and Bcl-2 [97]. Mono or combined treatment including gene therapy targeting vital genes such as p53, TERT, and Bik, is a promising new direction of study.

In addition, because immunotherapy such as "immune checkpoint" inhibition has been demonstrated to be a novel and effective treatment for solid tumors, it will also be valuable to confirm whether enhanced antitumor efficacy could be achieved through targeted therapy combined with immunotherapy.

\section{PERSPECTIVE AND FUTURE DIRECTION}

The concept of MTA combination therapy is still in its infancy and several problems have arisen in these pioneer studies. On one hand, the schema of most clinical studies is based on a "trial and error" model [98]. For the obscure landscape of cell signal networks and tumor escape mechanisms, the therapeutic combination approaches selected to date have largely been decided based on the empirical work of clinicians. On the other hand, it is hard to judge whether combination therapy is superior to targeted therapy alone because of the lack of an MTA control arm in most clinical trials. Besides, the criteria for eligible patients in these trials almost always exclude patients with specific genomic mutations or particular biomarkers, which may be the primary reason for the negative results in comparisons of MTA combination therapy. Combination therapy will become more precise and effective through screening of patients with potential benefits (Figure 2).

Deeper understanding of the mechanisms of tumor occurrence, progression, development, and metastasis will facilitate rational development and accelerate the adoption of MTA combination therapy in HCC. To confront the challenges of MTA combination therapy, a multi-disciplinary team approach, including precision medicine, may be desirable [99]. With the development of next-generation sequencing technology, the genomic profiles of patients with advanced HCC can now be obtained [100]. This may allow us to identify valuable mutations that could represent inhibition targets and guide clinicians in deciding which targets should be combined. More significantly, more potent antitumor effects might be observed by selecting the most appropriate patients to receive targeted combination therapy [43]. 
Most importantly, combining biopsy/rebiopsy and precise genome-wide sequencing can provide credible information and evidence concerning the tumor response to the targeted therapy [101]. Therefore, the importance of biopsy/rebiopsy in accurately identifying potential patients who will benefit from MTA combination therapy should be emphasized.

In conclusion, numerous studies have applied combination treatments based on targeted therapies in HCC, including targeted therapy plus chemotherapy, dual or multiple targeted therapy, targeted therapy plus radiotherapy, and targeted therapy plus TACE. Although some of these explorations yielded informative and promising results, the majority showed negative or even inferior outcomes. So far, there have been few triumphs with the application of combination therapy in the clinic despite encouraging results from in vitro studies. We do not yet have an effective therapeutic approach to control and cure advanced HCC in humans, and there is a long road ahead on the journey toward optimal tumor treatment.

\section{ACKNOWLEDGMENTS}

This work was supported by International Science and Technology Cooperation Projects (2015DFA30650 and 2010DFB33720), Capital Special Research Project for Health Development (2014-2-4012), capital research project for the characteristics clinical application (Z151100004015170), and Program for New Century Excellent Talents in University (NCET-11-0288).

\section{CONFLICTS OF INTEREST}

None of the authors have any conflicts of interest to disclose.

\section{REFERENCES}

1. Siegel RL, Miller KD and Jemal A. Cancer statistics, 2015. CA Cancer J Clin. 2015; 65:5-29.

2. Frenette $\mathrm{C}$ and Gish R. Targeted systemic therapies for hepatocellular carcinoma: clinical perspectives, challenges and implications. World journal of gastroenterology. 2012; 18:498-506.

3. El-Serag HB and Rudolph KL. Hepatocellular carcinoma: epidemiology and molecular carcinogenesis. Gastroenterology. 2007; 132:2557-2576.

4. Llovet JM and Bruix J. Systematic review of randomized trials for unresectable hepatocellular carcinoma: Chemoembolization improves survival. Hepatology (Baltimore, Md). 2003; 37:429-442.

5. Torimura T, Iwamoto H, Nakamura $T$, Koga H, Ueno T, Kerbel RS and Sata M. Metronomic chemotherapy: possible clinical application in advanced hepatocellular carcinoma.
Translational oncology. 2013; 6:511-519.

6. Giorgio A, Di Sarno A, De Stefano G, Scognamiglio U, Farella N, Mariniello A, Esposito V, Coppola C and Giorgio V. Percutaneous radiofrequency ablation of hepatocellular carcinoma compared to percutaneous ethanol injection in treatment of cirrhotic patients: an Italian randomized controlled trial. Anticancer research. 2011; 31:2291-2295.

7. Breous E and Thimme R. Potential of immunotherapy for hepatocellular carcinoma. Journal of hepatology. 2011; 54:830-834.

8. Llovet JM, Burroughs A and Bruix J. Hepatocellular carcinoma. Lancet (London, England). 2003; 362:19071917.

9. Brytska N, Han HS, Shehta A, Yoon YS, Cho JY and Choi Y. Laparoscopic liver resection for hepatitis B and C virusrelated hepatocellular carcinoma in patients with Child $\mathrm{B}$ or $\mathrm{C}$ cirrhosis. Hepatobiliary surgery and nutrition. 2015; 4:373-378

10. Llovet JM and Bruix J. Molecular targeted therapies in hepatocellular carcinoma. Hepatology (Baltimore, Md). 2008; 48:1312-1327.

11. Cervello M, McCubrey JA, Cusimano A, Lampiasi N, Azzolina A and Montalto G. Targeted therapy for hepatocellular carcinoma: novel agents on the horizon. Oncotarget. 2012; 3:236-260. doi: 10.18632/oncotarget.466.

12. Llovet JM, Ricci S, Mazzaferro V, Hilgard P, Gane E, Blanc JF, de Oliveira AC, Santoro A, Raoul JL, Forner A, Schwartz M, Porta C, Zeuzem S, Bolondi L, Greten TF, Galle PR, et al. Sorafenib in advanced hepatocellular carcinoma. The New England journal of medicine. 2008; 359:378-390.

13. Cheng AL, Kang YK, Chen Z, Tsao CJ, Qin S, Kim JS, Luo R, Feng J, Ye S, Yang TS, Xu J, Sun Y, Liang H, Liu J, Wang J, Tak WY, et al. Efficacy and safety of sorafenib in patients in the Asia-Pacific region with advanced hepatocellular carcinoma: a phase III randomised, doubleblind, placebo-controlled trial. The Lancet Oncology. 2009; 10:25-34.

14. Llovet JM, Villanueva A, Lachenmayer A and Finn RS. Advances in targeted therapies for hepatocellular carcinoma in the genomic era. Nature reviews Clinical oncology. 2015; 12:408-424.

15. Kemp JA, Shim MS, Heo CY and Kwon YJ. "Combo" nanomedicine: Co-delivery of multi-modal therapeutics for efficient, targeted, and safe cancer therapy. Advanced drug delivery reviews. 2016; 98:3-18.

16. Ingle PV, Samsudin SZ, Chan PQ, Ng MK, Heng LX, Yap SC, Chai AS and Wong AS. Development and novel therapeutics in hepatocellular carcinoma: a review. Therapeutics and clinical risk management. 2016; 12:445455.

17. Gottesman MM and Pastan I. Biochemistry of multidrug resistance mediated by the multidrug transporter. Annual review of biochemistry. 1993; 62:385-427. 
18. Kim CA, Spratlin JL, Armstrong DE, Ghosh S and Mulder KE. Efficacy and safety of single agent or combination adjuvant chemotherapy in elderly patients with colon cancer: a Canadian cancer institute experience. Clinical colorectal cancer. 2014; 13:199-206.

19. Zheng Z, Liang W, Wang D, Schroder PM, Ju W, Wu L, Zheng Z, Shang Y, Guo Z and He X. Adjuvant chemotherapy for patients with primary hepatocellular carcinoma: a meta-analysis. Int J Cancer. 2015; 136:E751759 .

20. Viens P, Tarpin C, Roche H and Bertucci F. Systemic therapy of inflammatory breast cancer from high-dose chemotherapy to targeted therapies: the French experience. Cancer. 2010; 116:2829-2836.

21. Nguyen KQ, Tsou WI, Calarese DA, Kimani SG, Singh S, Hsieh S, Liu Y, Lu B, Wu Y, Garforth SJ, Almo SC, Kotenko SV and Birge RB. Overexpression of MERTK receptor tyrosine kinase in epithelial cancer cells drives efferocytosis in a gain-of-function capacity. The Journal of biological chemistry. 2014; 289:25737-25749.

22. Abou-Alfa GK, Johnson P, Knox JJ, Capanu M, Davidenko I, Lacava J, Leung T, Gansukh B and Saltz LB. Doxorubicin plus sorafenib vs doxorubicin alone in patients with advanced hepatocellular carcinoma: a randomized trial. Jama. 2010; 304:2154-2160.

23. Tacar O, Sriamornsak P and Dass CR. Doxorubicin: an update on anticancer molecular action, toxicity and novel drug delivery systems. The Journal of pharmacy and pharmacology. 2013; 65:157-170.

24. Wakabayashi I and Groschner K. Vascular actions of anthracycline antibiotics. Current medicinal chemistry. 2003; 10:427-436.

25. McCubrey JA, Steelman LS, Abrams SL, Lee JT, Chang F, Bertrand FE, Navolanic PM, Terrian DM, Franklin RA, D'Assoro AB, Salisbury JL, Mazzarino MC, Stivala $\mathrm{F}$ and Libra M. Roles of the RAF/MEK/ERK and PI3K/ PTEN/AKT pathways in malignant transformation and drug resistance. Advances in enzyme regulation. 2006; 46:249279.

26. Chiorean EG, Ramasubbaiah R, Yu M, Picus J, Bufill JA, Tong Y, Coleman N, Johnston EL, Currie C and Loehrer PJ. Phase II trial of erlotinib and docetaxel in advanced and refractory hepatocellular and biliary cancers: Hoosier Oncology Group GI06-101. Oncologist. 2012; 17:13.

27. Khan I, Morris S, Hackshaw A and Lee SM. Costeffectiveness of first-line erlotinib in patients with advanced non-small-cell lung cancer unsuitable for chemotherapy. BMJ open. 2015; 5:e006733.

28. Blay JY. [Anti-angiogenetic agents for solid tumors]. [Article in French]. 2007; 28 Suppl 1:S7-8.

29. Ferrara $\mathrm{N}$ and Kerbel RS. Angiogenesis as a therapeutic target. Nature. 2005; 438:967-974.

30. Fang P, Hu JH, Cheng ZG, Liu ZF, Wang JL and Jiao SC. Efficacy and safety of bevacizumab for the treatment of advanced hepatocellular carcinoma: a systematic review of phase II trials. PloS one. 2012; 7:e49717.

31. Boige V, Malka D, Bourredjem A, Dromain C, Baey C, Jacques N, Pignon JP, Vimond N, Bouvet-Forteau N, De Baere T, Ducreux M and Farace F. Efficacy, safety, and biomarkers of single-agent bevacizumab therapy in patients with advanced hepatocellular carcinoma. Oncologist. 2012; 17:1063-1072.

32. Hurwitz H, Fehrenbacher L, Novotny W, Cartwright T, Hainsworth J, Heim W, Berlin J, Baron A, Griffing S, Holmgren E, Ferrara N, Fyfe G, Rogers B, Ross R and Kabbinavar F. Bevacizumab plus irinotecan, fluorouracil, and leucovorin for metastatic colorectal cancer. The New England journal of medicine. 2004; 350:2335-2342.

33. Xiong YQ, Sun HC, Zhu XD, Zhang W, Zhuang PY, Zhang JB, Xu HX, Kong LQ, Wu WZ, Qin LX and Tang ZY. Bevacizumab enhances chemosensitivity of hepatocellular carcinoma to adriamycin related to inhibition of survivin expression. Journal of cancer research and clinical oncology. 2011; 137:505-512.

34. Beppu T, Emi Y, Tokunaga S, Oki E, Shirabe K, Ueno S, Kuramoto M, Kabashima A, Takahashi I, Samura H, Eguchi S, Akagi Y, Natsugoe S, Ogata Y, Kakeji Y, Baba H, et al. Liver resectability of advanced liver-limited colorectal liver metastases following mFOLFOX6 with bevacizumab (KSCC0802 Study). Anticancer research. 2014; 34:66556662.

35. Zhu AX, Blaszkowsky LS, Ryan DP, Clark JW, Muzikansky A, Horgan K, Sheehan S, Hale KE, Enzinger PC, Bhargava P and Stuart K. Phase II study of gemcitabine and oxaliplatin in combination with bevacizumab in patients with advanced hepatocellular carcinoma. J Clin Oncol. 2006; 24:1898-1903.

36. Sun W, Sohal D, Haller DG, Mykulowycz K, Rosen M, Soulen MC, Caparro M, Teitelbaum UR, Giantonio B, O'Dwyer PJ, Shaked A, Reddy R and Olthoff K. Phase 2 trial of bevacizumab, capecitabine, and oxaliplatin in treatment of advanced hepatocellular carcinoma. Cancer. 2011; 117:3187-3192.

37. Hsu CH, Yang TS, Hsu C, Toh HC, Epstein RJ, Hsiao LT, Chen PJ, Lin ZZ, Chao TY and Cheng AL. Efficacy and tolerability of bevacizumab plus capecitabine as first-line therapy in patients with advanced hepatocellular carcinoma. Br J Cancer. 2010; 102:981-986.

38. Granito A, Marinelli S, Terzi E, Piscaglia F, Renzulli M, Venerandi L, Benevento F and Bolondi L. Metronomic capecitabine as second-line treatment in hepatocellular carcinoma after sorafenib failure. Digestive and liver disease. 2015; 47:518-522.

39. Cunningham D, Humblet Y, Siena S, Khayat D, Bleiberg H, Santoro A, Bets D, Mueser M, Harstrick A, Verslype C, Chau I and Van Cutsem E. Cetuximab monotherapy and cetuximab plus irinotecan in irinotecan-refractory metastatic colorectal cancer. The New England journal of medicine. 2004; 351:337-345. 
40. Asnacios A, Fartoux L, Romano O, Tesmoingt C, Louafi SS, Mansoubakht T, Artru P, Poynard T, Rosmorduc O, Hebbar $M$ and Taieb J. Gemcitabine plus oxaliplatin (GEMOX) combined with cetuximab in patients with progressive advanced stage hepatocellular carcinoma: results of a multicenter phase 2 study. Cancer. 2008; 112:2733-2739.

41. Huang SM and Harari PM. Epidermal growth factor receptor inhibition in cancer therapy: biology, rationale and preliminary clinical results. Invest New Drugs. 1999; $17: 259-269$.

42. Villanueva A and Llovet JM. Second-line therapies in hepatocellular carcinoma: emergence of resistance to sorafenib. Clin Cancer Res. 2012; 18:1824-1826.

43. Chan SL, Wong AM, Lee K, Wong $\mathrm{N}$ and Chan AK. Personalized therapy for hepatocellular carcinoma: Where are we now? Cancer Treat Rev. 2016; 45:77-86.

44. Stegmeier F, Warmuth M, Sellers WR and Dorsch M. Targeted cancer therapies in the twenty-first century: lessons from imatinib. Clinical pharmacology and therapeutics. 2010; 87:543-552.

45. Groenendijk FH and Bernards R. Drug resistance to targeted therapies: deja vu all over again. Mol Oncol. 2014; 8:10671083.

46. Ribatti D. Novel angiogenesis inhibitors: addressing the issue of redundancy in the angiogenic signaling pathway. Cancer Treat Rev. 2011; 37:344-352.

47. Wang X, Goldstein D, Crowe PJ, Yang M, Garrett K, Zeps $\mathrm{N}$ and Yang JL. Overcoming resistance of targeted egfr monotherapy by inhibition of stat 3 escape pathway in soft tissue sarcoma. Oncotarget. 2016; 7:21496-509. doi: 10.18632/oncotarget.7452.

48. Johannessen CM, Boehm JS, Kim SY, Thomas SR, Wardwell L, Johnson LA, Emery CM, Stransky N, Cogdill AP, Barretina J, Caponigro G, Hieronymus H, Murray RR, Salehi-Ashtiani K, Hill DE, Vidal M, et al. COT drives resistance to RAF inhibition through MAP kinase pathway reactivation. Nature. 2010; 468:968-972.

49. Burrell RA, McGranahan N, Bartek J and Swanton C. The causes and consequences of genetic heterogeneity in cancer evolution. Nature. 2013; 501:338-345.

50. Gerlinger M, Rowan AJ, Horswell S, Larkin J, Endesfelder D, Gronroos E, Martinez P, Matthews N, Stewart A, Tarpey P, Varela I, Phillimore B, Begum S, McDonald NQ, Butler $\mathrm{A}$, Jones D, et al. Intratumor heterogeneity and branched evolution revealed by multiregion sequencing. The New England journal of medicine. 2012; 366:883-892.

51. Lawrence MS, Stojanov P, Polak P, Kryukov GV, Cibulskis K, Sivachenko A, Carter SL, Stewart C, Mermel CH, Roberts SA, Kiezun A, Hammerman PS, McKenna A, Drier Y, Zou L, Ramos AH, et al. Mutational heterogeneity in cancer and the search for new cancer-associated genes. Nature. 2013; 499:214-218.

52. Miao R, Luo H, Zhou H, Li G, Bu D, Yang X, Zhao X,
Zhang H, Liu S, Zhong Y, Zou Z, Zhao Y, Yu K, He L, Sang X, Zhong S, et al. Identification of prognostic biomarkers in hepatitis B virus-related hepatocellular carcinoma and stratification by integrative multi-omics analysis. Journal of hepatology. 2014; 61:840-849.

53. Xue R, Li R, Guo H, Guo L, Su Z, Ni X, Qi L, Zhang T, Li Q, Zhang Z, Xie XS, Bai F and Zhang N. Variable IntraTumor Genomic Heterogeneity of Multiple Lesions in Patients With Hepatocellular Carcinoma. Gastroenterology. 2016.

54. Ibrahim N, Yu Y, Walsh WR and Yang JL. Molecular targeted therapies for cancer: sorafenib mono-therapy and its combination with other therapies (review). Oncol Rep. 2012; 27:1303-1311.

55. Hida K, Maishi N, Torii C and Hida Y. Tumor angiogenesischaracteristics of tumor endothelial cells. International journal of clinical oncology. 2016; 21:206-212.

56. Hui L and Chen Y. Tumor microenvironment: Sanctuary of the devil. Cancer letters. 2015; 368:7-13.

57. Whittaker $\mathrm{S}$, Marais $\mathrm{R}$ and Zhu AX. The role of signaling pathways in the development and treatment of hepatocellular carcinoma. Oncogene. 2010; 29:4989-5005.

58. Gui Y, Yeganeh M, Donates YC, Tobelaim WS, Chababi W, Mayhue M, Yoshimura A, Ramanathan S, Saucier C and Ilangumaran S. Regulation of MET receptor tyrosine kinase signaling by suppressor of cytokine signaling 1 in hepatocellular carcinoma. Oncogene. 2015; 34:5718-5728.

59. Weber GF. Why does cancer therapy lack effective antimetastasis drugs? Cancer letters. 2013; 328:207-211.

60. Thomas MB, Morris JS, Chadha R, Iwasaki M, Kaur H, Lin E, Kaseb A, Glover K, Davila M and Abbruzzese J. Phase II trial of the combination of bevacizumab and erlotinib in patients who have advanced hepatocellular carcinoma. J Clin Oncol. 2009; 27:843-850.

61. Hsu CH, Kang YK, Yang TS, Shun CT, Shao YY, Su WC, Sandoval-Tan J, Chiou TJ, Jin K, Hsu C and Cheng AL. Bevacizumab with erlotinib as first-line therapy in Asian patients with advanced hepatocellular carcinoma: a multicenter phase II study. Oncology. 2013; 85:44-52.

62. Fuchs BC, Hoshida Y, Fujii T, Wei L, Yamada S, Lauwers GY, McGinn CM, DePeralta DK, Chen X, Kuroda T, Lanuti M, Schmitt AD, Gupta S, Crenshaw A, Onofrio R, Taylor B, et al. Epidermal growth factor receptor inhibition attenuates liver fibrosis and development of hepatocellular carcinoma. Hepatology (Baltimore, Md). 2014; 59:15771590 .

63. Kuczynski EA, Lee CR, Man S, Chen E and Kerbel RS. Effects of Sorafenib Dose on Acquired Reversible Resistance and Toxicity in Hepatocellular Carcinoma. Cancer research. 2015; 75:2510-2519.

64. Zhu AX, Rosmorduc O, Evans TR, Ross PJ, Santoro A, Carrilho FJ, Bruix J, Qin S, Thuluvath PJ, Llovet JM, Leberre MA, Jensen M, Meinhardt G and Kang YK. SEARCH: a phase III, randomized, double-blind, placebo- 
controlled trial of sorafenib plus erlotinib in patients with advanced hepatocellular carcinoma. J Clin Oncol. 2015; 33:559-566.

65. Llovet JM, Decaens T, Raoul JL, Boucher E, Kudo M, Chang C, Kang YK, Assenat E, Lim HY, Boige V, Mathurin P, Fartoux L, Lin DY, Bruix J, Poon RT, Sherman $\mathrm{M}$, et al. Brivanib in patients with advanced hepatocellular carcinoma who were intolerant to sorafenib or for whom sorafenib failed: results from the randomized phase III BRISK-PS study. J Clin Oncol. 2013; 31:3509-3516.

66. Janku F, Kaseb AO, Tsimberidou AM, Wolff RA and Kurzrock R. Identification of novel therapeutic targets in the PI3K/AKT/mTOR pathway in hepatocellular carcinoma using targeted next generation sequencing. Oncotarget. 2014; 5:3012-3022. doi: 10.18632/oncotarget.1687.

67. Tommasi S, Pinto R, Pilato B and Paradiso A. Molecular pathways and related target therapies in liver carcinoma. Current pharmaceutical design. 2007; 13:3279-3287.

68. Rudalska R, Dauch D, Longerich T, McJunkin K, Wuestefeld T, Kang TW, Hohmeyer A, Pesic M, Leibold J, von Thun A, Schirmacher P, Zuber J, Weiss KH, Powers S, Malek NP, Eilers M, et al. In vivo RNAi screening identifies a mechanism of sorafenib resistance in liver cancer. Nature medicine. 2014; 20:1138-1146.

69. Koh YW, Shah MH, Agarwal K, McCarty SK, Koo BS, Brendel VJ, Wang C, Porter K, Jarjoura D, Saji M and Ringel MD. Sorafenib and Mek inhibition is synergistic in medullary thyroid carcinoma in vitro. Endocrine-related cancer. 2012; 19:29-38.

70. Lim HY, Heo J, Choi HJ, Lin CY, Yoon JH, Hsu C, Rau KM, Poon RT, Yeo W, Park JW, Tay MH, Hsieh WS, Kappeler C, Rajagopalan P, Krissel H, Jeffers M, et al. A phase II study of the efficacy and safety of the combination therapy of the MEK inhibitor refametinib (BAY 869766) plus sorafenib for Asian patients with unresectable hepatocellular carcinoma. Clin Cancer Res. 2014; 20:59765985.

71. Shimizu T, Tolcher AW, Papadopoulos KP, Beeram M, Rasco DW, Smith LS, Gunn S, Smetzer L, Mays TA, Kaiser B, Wick MJ, Alvarez C, Cavazos A, Mangold GL and Patnaik A. The clinical effect of the dual-targeting strategy involving PI3K/AKT/mTOR and RAS/MEK/ERK pathways in patients with advanced cancer. Clin Cancer Res. 2012; 18:2316-2325.

72. Llovet JM, Real MI, Montana X, Planas R, Coll S, Aponte J, Ayuso C, Sala M, Muchart J, Sola R, Rodes J and Bruix J. Arterial embolisation or chemoembolisation versus symptomatic treatment in patients with unresectable hepatocellular carcinoma: a randomised controlled trial. Lancet (London, England). 2002; 359:1734-1739.

73. Lin XJ, Li QJ, Lao XM, Yang H and Li SP. Transarterial injection of recombinant human type- 5 adenovirus H101 in combination with transarterial chemoembolization (TACE) improves overall and progressive-free survival in unresectable hepatocellular carcinoma (HCC). BMC cancer.
$2015 ; 15: 707$.

74. Tsurusaki M and Murakami T. Surgical and Locoregional Therapy of HCC: TACE. Liver Cancer. 2015; 4:165-175.

75. Xiao EH, Guo D and Bian DJ. Effect of preoperative transcatheter arterial chemoembolization on angiogenesis of hepatocellular carcinoma cells. World journal of gastroenterology. 2009; 15:4582-4586.

76. Larkin J, Chiarion-Sileni V, Gonzalez R, Grob JJ, Cowey CL, Lao CD, Schadendorf D, Dummer R, Smylie M, Rutkowski P, Ferrucci PF, Hill A, Wagstaff J, Carlino MS, Haanen JB, Maio M, et al. Combined Nivolumab and Ipilimumab or Monotherapy in Untreated Melanoma. N Engl J Med. 2015; 373:23-34.

77. Wu XZ, Xie GR and Chen D. Hypoxia and hepatocellular carcinoma: The therapeutic target for hepatocellular carcinoma. Journal of gastroenterology and hepatology. 2007; 22:1178-1182.

78. Arizumi T, Ueshima K, Minami T, Kono M, Chishina H, Takita M, Kitai S, Inoue T, Yada N, Hagiwara S, Minami Y, Sakurai T, Nishida N and Kudo M. Effectiveness of Sorafenib in Patients with Transcatheter Arterial Chemoembolization (TACE) Refractory and IntermediateStage Hepatocellular Carcinoma. Liver Cancer. 2015; 4:253-262.

79. Abdel-Rahman $\mathrm{O}$ and Elsayed ZA. Combination trans arterial chemoembolization (TACE) plus sorafenib for the management of unresectable hepatocellular carcinoma: a systematic review of the literature. Digestive diseases and sciences. 2013; 58:3389-3396.

80. Jiang H, Meng Q, Tan H, Pan S, Sun B, Xu R and Sun $X$. Antiangiogenic therapy enhances the efficacy of transcatheter arterial embolization for hepatocellular carcinomas. Int J Cancer. 2007; 121:416-424.

81. Zhang $\mathrm{L}, \mathrm{Hu} \mathrm{P}$, Chen $\mathrm{X}$ and Bie P. Transarterial chemoembolization (TACE) plus sorafenib versus TACE for intermediate or advanced stage hepatocellular carcinoma: a meta-analysis. PloS one. 2014; 9:e100305.

82. Geschwind JF, Kudo M, Marrero JA, Venook AP, Chen XP, Bronowicki JP, Dagher L, Furuse J, Ladron de Guevara L, Papandreou C, Sanyal AJ, Takayama T, Ye SL, Yoon SK, Nakajima K, Lehr R, et al. TACE Treatment in Patients with Sorafenib-treated Unresectable Hepatocellular Carcinoma in Clinical Practice: Final Analysis of GIDEON. Radiology. 2016:150667.

83. Lencioni R, Llovet JM, Han G, Tak WY, Yang J, Guglielmi A, Paik SW, Reig M, Kim DY, Chau GY, Luca A, Del Arbol LR, Leberre MA, Niu W, Nicholson K, Meinhardt $\mathrm{G}$, et al. Sorafenib or placebo plus TACE with doxorubicineluting beads for intermediate stage HCC: The SPACE trial. Journal of hepatology. 2016.

84. Kudo M, Han G, Finn RS, Poon RT, Blanc JF, Yan L, Yang J, Lu L, Tak WY, Yu X, Lee JH, Lin SM, Wu C, Tanwandee T, Shao G, Walters IB, et al. Brivanib as adjuvant therapy to transarterial chemoembolization in 
patients with hepatocellular carcinoma: A randomized phase III trial. Hepatology (Baltimore, Md). 2014; 60:16971707.

85. Tsai CL, Hsu FM, Tzen KY, Liu WL, Cheng AL and Cheng JC. Sonic Hedgehog inhibition as a strategy to augment radiosensitivity of hepatocellular carcinoma. Journal of gastroenterology and hepatology. 2015; 30:1317-1324.

86. Kan X, Jing Y, Wan QY, Pan JC, Han M, Yang Y, Zhu M, Wang $Q$ and Liu KH. Sorafenib combined with percutaneous radiofrequency ablation for the treatment of medium-sized hepatocellular carcinoma. European review for medical and pharmacological sciences. 2015; 19:247255.

87. Feng X, Xu R, Du X, Dou K, Qin X, Xu J, Jia W, Wang Z, Zhao H, Yang S, Guo C, Liu T and Ma K. Combination therapy with sorafenib and radiofrequency ablation for BCLC Stage 0-B1 hepatocellular carcinoma: a multicenter retrospective cohort study. The American journal of gastroenterology. 2014; 109:1891-1899.

88. Curtit E, Thiery-Vuillemin A, Nguyen T, Heyd B, Pivot X, Di Martino $\mathrm{V}$ and Borg C. Complete histologic response induced by sorafenib in advanced hepatocellular carcinoma: a case report. J Clin Oncol. 2011; 29:e330-332.

89. Han ZG. Functional genomic studies: insights into the pathogenesis of liver cancer. Annu Rev Genomics Hum Genet. 2012; 13:171-205.

90. Li G, Ye L, Pan J, Long M, Zhao Z, Yang H, Tian J, Wen Y, Dong S, Guan J and Luo B. Antitumoural hydroxyapatite nanoparticles-mediated hepatoma-targeted trans-arterial embolization gene therapy: in vitro and in vivo studies. Liver international. 2012; 32:998-1007.

91. Said R, Hong DS, Warneke CL, Lee JJ, Wheler JJ, Janku F, Naing A, Falchook GS, Fu S, Piha-Paul S, Tsimberidou AM and Kurzrock R. P53 mutations in advanced cancers: clinical characteristics, outcomes, and correlation between progression-free survival and bevacizumab-containing therapy. Oncotarget. 2013; 4:705-714. doi: 10.18632/ oncotarget.974.

92. Li LY, Dai HY, Yeh FL, Kan SF, Lang J, Hsu JL, Jeng LB, Chen YH, Sher YP, Lin WC and Hung MC. Targeted hepatocellular carcinoma proapoptotic BikDD gene therapy. Oncogene. 2011; 30:1773-1783.

93. Yan B, Ouyang Q, Zhao Z, Cao F, Wang T, Jia X, Meng Y, Jiang S, Liu J, Chen R, Jia L, Zhang R, Wen W, Jin B, Chen $\mathrm{S}$, Zhao J, et al. Potent killing of HBV-related hepatocellular carcinoma by a chimeric protein of anti-HBsAg singlechain antibody and truncated Bid. Biomaterials. 2013; 34:4880-4889.

94. Sher YP, Tzeng TF, Kan SF, Hsu J, Xie X, Han Z, Lin WC, Li LY and Hung MC. Cancer targeted gene therapy of BikDD inhibits orthotopic lung cancer growth and improves long-term survival. Oncogene. 2009; 28:3286-3295.

95. Dai HY, Chen HY, Lai WC, Hung MC and Li LY. Targeted expression of BikDD combined with metronomic doxorubicin induces synergistic antitumor effect through Bax activation in hepatocellular carcinoma. Oncotarget. 2015; 6:23807-23819. doi: 10.18632/oncotarget.4278.

96. Hu BG, Liu LP, Chen GG, Ye CG, Leung KK, Ho RL, Lin MC and Lai PB. Therapeutic efficacy of improved alphafetoprotein promoter-mediated tBid delivered by folatePEI600-cyclodextrin nanopolymer vector in hepatocellular carcinoma. Experimental cell research. 2014; 324:183-191.

97. Li YM, Wen Y, Zhou BP, Kuo HP, Ding Q and Hung MC. Enhancement of Bik antitumor effect by Bik mutants. Cancer research. 2003; 63:7630-7633.

98. Mendelsohn J. Personalizing oncology: perspectives and prospects. J Clin Oncol. 2013; 31:1904-1911.

99. Habbab L, Alfaraidi H and Lamy A. Surviving catastrophic disintegration of a large left atrial myxoma: the importance of multi-disciplinary team. Journal of surgical case reports. $2014 ; 2014$.

100. Fujimoto A, Furuta M, Totoki Y, Tsunoda T, Kato M, Shiraishi Y, Tanaka H, Taniguchi H, Kawakami Y, Ueno M, Gotoh K, Ariizumi SI, Wardell CP, Hayami S, Nakamura T, Aikata $\mathrm{H}$, et al. Whole-genome mutational landscape and characterization of noncoding and structural mutations in liver cancer. Nature genetics. 2016.

101. Jekunen AP. Role of rebiopsy in relapsed non-small cell lung cancer for directing oncology treatments. Journal of oncology. 2015; 2015:809835.

102. Sanoff HK, Bernard S, Goldberg RM, Morse MA, Garcia R, Woods L, Moore DT and O'Neil BH. Phase II Study of Capecitabine, Oxaliplatin, and Cetuximab for Advanced Hepatocellular Carcinoma. Gastrointestinal cancer research. 2011; 4:78-83.

103. Santoro A, Rimassa L, Borbath I, Daniele B, Salvagni S, Van Laethem JL, Van Vlierberghe H, Trojan J, Kolligs FT, Weiss A, Miles S, Gasbarrini A, Lencioni M, Cicalese L, Sherman M, Gridelli C, et al. Tivantinib for secondline treatment of advanced hepatocellular carcinoma: a randomised, placebo-controlled phase 2 study. The Lancet Oncology. 2013; 14:55-63.

104. Knox JJ, Qin R, Strosberg JR, Tan B, Kaubisch A, ElKhoueiry AB, Bekaii-Saab TS, Rousey SR, Chen HX and Erlichman C. A phase II trial of bevacizumab plus temsirolimus in patients with advanced hepatocellular carcinoma. Invest New Drugs. 2015; 33:241-246.

105. Kelley RK, Nimeiri HS, Munster PN, Vergo MT, Huang Y, Li CM, Hwang J, Mulcahy MF, Yeh BM, Kuhn P, Luttgen MS, Grabowsky JA, Stucky-Marshall L, Korn WM, Ko AH, Bergsland EK, et al. Temsirolimus combined with sorafenib in hepatocellular carcinoma: a phase I dosefinding trial with pharmacokinetic and biomarker correlates. Ann Oncol. 2013; 24:1900-1907.

106. Kudo M, Imanaka K, Chida N, Nakachi K, Tak WY, Takayama T, Yoon JH, Hori T, Kumada H, Hayashi N, Kaneko S, Tsubouchi H, Suh DJ, Furuse J, Okusaka $\mathrm{T}$, Tanaka K, et al. Phase III study of sorafenib after 
transarterial chemoembolisation in Japanese and Korean patients with unresectable hepatocellular carcinoma. Eur J Cancer. 2011; 47:2117-2127.

107. Bai W, Wang YJ, Zhao Y, Qi XS, Yin ZX, He CY, Li RJ, Wu KC, Xia JL, Fan DM and Han GH. Sorafenib in combination with transarterial chemoembolization improves the survival of patients with unresectable hepatocellular carcinoma: a propensity score matching study. Journal of digestive diseases. 2013; 14:181-190.

108. Sansonno D, Lauletta G, Russi S, Conteduca V, Sansonno $\mathrm{L}$ and Dammacco F. Transarterial chemoembolization plus sorafenib: a sequential therapeutic scheme for HCV-related intermediate-stage hepatocellular carcinoma: a randomized clinical trial. Oncologist. 2012; 17:359-366.

109. Muhammad A, Dhamija M, Vidyarthi G, Amodeo D, Boyd W, Miladinovic B and Kumar A. Comparative effectiveness of traditional chemoembolization with or without sorafenib for hepatocellular carcinoma. World journal of hepatology. 2013; 5:364-371.

110. Choi GH, Shim JH, Kim MJ, Ryu MH, Ryoo BY, Kang YK, Shin YM, Kim KM, Lim YS and Lee HC. Sorafenib alone versus sorafenib combined with transarterial chemoembolization for advanced-stage hepatocellular carcinoma: results of propensity score analyses. Radiology. 2013; 269:603-611.

111. Qu XD, Chen CS, Wang JH, Yan ZP, Chen JM, Gong GQ, Liu QX, Luo JJ, Liu LX, Liu R and Qian S. The efficacy of TACE combined sorafenib in advanced stages hepatocellullar carcinoma. BMC cancer. 2012; 12:263.
112. Pinter M, Ulbrich G, Sieghart W, Kolblinger C, Reiberger T, Li S, Ferlitsch A, Muller C, Lammer J and PeckRadosavljevic M. Hepatocellular Carcinoma: A Phase II Randomized Controlled Double-Blind Trial of Transarterial Chemoembolization in Combination with Biweekly Intravenous Administration of Bevacizumab or a Placebo. Radiology. 2015; 277:903-912.

113. Britten CD, Gomes AS, Wainberg ZA, Elashoff D, Amado R, Xin Y, Busuttil RW, Slamon DJ and Finn RS. Transarterial chemoembolization plus or minus intravenous bevacizumab in the treatment of hepatocellular cancer: a pilot study. BMC cancer. 2012; 12:16.

114. Chen J, Zhou C, Long Y and Yin X. Sunitinib combined with transarterial chemoembolization versus transarterial chemoembolization alone for advanced-stage hepatocellular carcinoma: a propensity score matching study. Tumour biology. 2015; 36:183-191.

115. Pokuri VK, Tomaszewski GM, Ait-Oudhia S, Groman A, Khushalani NI, Lugade AA, Thanavala Y, Ashton EA, Grande C, Fetterly GJ and Iyer R. Efficacy, Safety, and Potential Biomarkers of Sunitinib and Transarterial Chemoembolization (TACE) Combination in Advanced Hepatocellular Carcinoma (HCC): Phase II Trial. American journal of clinical oncology. 2016.

116. Fukuda H, Numata K, Moriya S, Shimoyama Y, Ishii T, Nozaki A, Kondo M, Morimoto M, Maeda S, Sakamaki K, Morita S and Tanaka K. Hepatocellular carcinoma: concomitant sorafenib promotes necrosis after radiofrequency ablation - propensity score matching analysis. Radiology. 2014; 272:598-604. 